\title{
Cropping System Diversification Reduces Severity and Incidence of Soybean Sudden Death Syndrome Caused by Fusarium virguliforme
}

L. F. S. Leandro, ${ }^{\dagger}$ S. Eggenberger, C. Chen, J. Williams, and G. A. Beattie, Department of Plant Pathology and Microbiology; and M. Liebman, Department of Agronomy, Iowa State University, Ames 50011

\begin{abstract}
Current management of sudden death syndrome (SDS) of soybean, caused by Fusarium virguliforme, focuses on planting resistant varieties and improving soil drainage; however, these measures are not completely effective. A 6-year study evaluated the effects of cropping system diversification on SDS and soybean yield. SDS, root health, yield, and $F$. virguliforme density in soil were assessed in a naturally infested field trial comparing a 2-year cropping system consisting of a corn-soybean rotation and synthetic fertilizer applications with 3- and 4-year cropping systems consisting of corn-soybean-oat + red clover and corn-soybean-oat + alfalfa-alfalfa rotations, respectively, with both manure and low synthetic

fertilizer rates. In 5 of 6 years, SDS incidence and severity were lower and yield higher in the 3-and 4-year systems than in the 2-year system. SDS severity and incidence were up to 17 -fold lower in the diversified systems than in the 2-year system. Incidence and severity of SDS explained 45 to $87 \%$ of the variation in yield. Plants in the 2 -year system generally showed more severe root rot and lower plant weights than plants in the diversified systems. $F$. virguliforme density in soil was up to fivefold greater in the 2-year system compared with the 4-year system. The processes responsible for the suppression of SDS and yield protection in the diversified cropping systems still need to be determined.
\end{abstract}

Soybean (Glycine max (L.) Merrill) sudden death syndrome (SDS) is a disease of major importance in North and South America (Hartman et al. 2015a; Wrather et al. 2010). Estimates of annual yield losses in the United States due to SDS have ranged between 0.6 and 1.9 million metric tons during the years from 2006 to 2014 (Allen et al. 2017), accounting for $\$ 200$ to 750 million in monetary losses (Navi and Yang, 2016a). In North America, the soilborne fungus Fusarium virguliforme causes SDS (Aoki and O'Donnell 2003) but additional species cause the disease in South America (Aoki et al. 2012). Infection occurs through the roots in early soybean growth stages (Gao et al. 2006; Rupe and Gbur 1995) and is favored by cool soil temperatures (Gongora-Canul and Leandro 2011b; Scherm and Yang, 1999). Plants infected by $F$. virguliforme can develop root symptoms characterized by brown discoloration and poor root development (Hartman et al. 2015b), and foliar symptoms characterized by interveinal chlorosis and necrosis, followed by premature defoliation and senescence (Roy et al. 1997). Foliar symptoms typically develop during soybean reproductive stages and are caused by $F$. virguliforme phytotoxins that are moved from the roots to the shoots in the plant's vascular system (Brar et al. 2011; Huang and Hartman 1998). The expression of foliar symptoms is favored by abundant soil moisture (Leandro et al. 2013; Scherm and Yang 1996); therefore, it is possible for plants to be infected without showing visible foliar symptoms when field soil conditions are dry.

Existing management of SDS currently emphasizes using resistant varieties, improving soil drainage, and reducing soil compaction

Current address of S. Chen: Valent Biosciences LLC., Long Grove, IL 60047.

${ }^{\dagger}$ Corresponding author: L. F. S. Leandro; E-mail: 1leandro@iastate.edu

Funding: This project was funded by the Iowa Soybean Association, the Leopold Center for Sustainable Agriculture (projects 2010-E02, 2013-XP01, and 2014-XP01), the United States Department of Agriculture (project 201467013-21712), and the Bi-national Agriculture Research and Development Fund (project US-4550-12).

*The $\boldsymbol{e}$-Xtra logo stands for "electronic extra" and indicates that three supplementary tables are published online.

Accepted for publication 9 March 2018.

() 2018 The American Phytopathological Society
(Hartman et al. 2015a; Leandro et al. 2012). More recently, a fungicide treatment has been shown to reduce SDS and confer a yield benefit when applied as a seed treatment (Kandel et al. 2016a; Weems et al. 2015). However, none of these approaches is completely effective against the disease. Soybean resistance to SDS is controlled by multiple genes (Lightfoot 2015), and even the most resistant varieties can develop SDS under favorable conditions, particularly in fields with high inoculum pressure and abundant soil moisture (de Farias Neto et al. 2006; Kandel et al. 2016a; Scherm et al. 1998). Cultural practices that improve soil drainage can help manage SDS but their effectiveness can be highly dependent on environmental conditions. Delayed planting has been reported to reduce SDS (Hershman et al. 1990) but a more recent multistate study found no consistent effect of planting date on SDS and no correlation between soil temperature and SDS development (Kandel et al. 2016b).

Crop rotation can be a valuable approach for maintaining soil fertility, enhancing crop productivity, improving yield stability, and suppressing certain insect pests, weeds, and plant pathogens (Ball et al. 2005; Gaudin et al. 2015; Karlen et al. 1994; Kirkegaard et al. 2008; Liebman and Staver 2001). However, the widespread use of synthetic fertilizers and pesticides has favored the prevalence of short rotation sequences and, in some cases, the production of crops in continuous monocultures (Power and Follett 1987). Crops grown in short rotations and monocultures often yield considerably less than in extended rotations, even when treated with agrichemicals (Bennett et al. 2012). In a substantial number of cases, this yield decline has been attributed to soil microorganisms that are affected by cropping system diversity (Bennett et al. 2012; Kirkegaard et al. 2008).

The impact of cropping system diversification on SDS is not well understood but several studies have suggested that crop rotations can affect SDS development. For example, $F$. virguliforme density in soil was lower when soybean was in rotations with wheat and sorghum than when soybean was in rotation with fescue (Rupe et al. 1997). In an Argentinian study focused on the SDS-causing species $F$. crassistipitatum, SDS severity was lower in a soybean rotation with corn than in a soybean monoculture (Perez-Brandan et al. 2014). However, rotations do not eliminate SDS, because SDS outbreaks have been reported in soybean fields following rotations with wheat, sorghum, corn, fescue, rice, and cotton (Rupe et al. 1997). Other studies, in contrast, have suggested that the corn-soybean rotation common in the Midwestern United States is associated with increased rather than decreased $F$. virguliforme density in soil (Navi and Yang 2016b; Westphal and Xing 2011; Xing and Westphal 2009). 
The loss of crop diversity in the Midwestern United States, due especially to reductions in small grain, hay, and pasture production, is linked with significant reductions in livestock production in the region (Sulc and Tracy 2007). Consequently, the application of manure to cropland became less common (Magdoff et al. 1997). Application of manure can promote nutrient recycling, maintenance of soil organic matter (Russelle et al. 2007), and suppression of certain soilborne diseases through changes in soil chemical, physical, and biological characteristics (Bailey and Lazarovits 2003). The impact of composted manure applications on SDS is poorly understood (Marzano et al. 2015).

The objective of this study was to assess the effects of cropping system diversification, encompassing both crop rotations and composted manure amendments, on soybean SDS, soil pathogen populations, root health, and yield under field conditions. This study was conducted on a naturally infested field with a long-term history of cropping system diversification treatments in Iowa.

\section{Materials and Methods}

Design and management of the experiment. Work reported in this study was conducted during 2010 to 2015 within a cropping systems experiment initiated in 2001 at Iowa State University (ISU)'s Marsden Farm in Boone County, IA (Davis et al. 2012; Gómez et al. 2012; Liebman et al. 2008). The experiment was established with the goal of comparing agronomics, weed management, and economics between the corn-soybean system that predominates the Midwestern United States and more diversified cropping systems comprising longer crop rotations and composted manure amendments. In 2010, there was a severe outbreak of SDS at the Marsden Farm site (Leandro et al. 2013) that resulted in the fortuitous observation of differences in SDS development among the cropping systems. This initiated the 6-year study reported here on the impact of cropping system diversification on SDS. Soils at the site are Mollisols, including Clarion loam and Webster silty clay loam, and were naturally infested with $F$. virguliforme. Temperature and precipitation data were collected $1 \mathrm{~km}$ from the study site (Supplementary Table S1).

The experiment followed a randomized complete block split-plot design with four blocks. Main plots ( 18 by $84 \mathrm{~m}$ ) were assigned to three cropping systems and subplots ( 9 by $84 \mathrm{~m}$ ) were assigned to two weed management regimes (Table 1 ). No artificial $F$. virguliforme inoculum was added to the field plots.

Cropping system-Main plots. Main plot treatments were 2year, 3-year, and 4-year cropping systems defined by crop rotation and fertility regime (Table 1). The 2-year cropping system consisted of a corn (Zea mays L.)-soybean rotation managed with practices typically used in the region. Synthetic fertilizers were applied at standard rates based on soil test information (Supplementary Table S2). The 3 year and 4-year cropping systems were intended to represent farming systems that integrate livestock with diversified crop production. Consequently, the 3-year corn-soybean-oat (Avena sativa L.) + red clover (Trifolium pratense L.) rotation and the 4-year cornsoybean-oat + alfalfa (Medicago sativa $\mathrm{L}$.)-alfalfa rotation were managed with applications of composted cattle manure and reduced rates of synthetic fertilizers.

Corn and soybean were grown for grain, oat was grown for grain and straw, alfalfa was grown for hay, and red clover was grown solely as a cover crop. Because each crop phase within each rotation was grown each year, there were nine main plots in each of the four replicate blocks (Fig. 1). Soybean was grown following corn in each of the different crop rotations. After harvest, corn stalks were shredded mechanically and plots were tilled with a chisel plow to a depth of 30 to $35 \mathrm{~cm}$. The following spring, soybean plots were leveled with a field cultivator before planting. Soybean was sown in mid to late May each year (Table 1); in 2010 and 2014, separate blocks of replicates were planted a week apart due to variation in soil moisture conditions within the field.

Composted manure was produced at the ISU Compost Facility (http://farms.ag.iastate.edu/compost-facility-pdf), using a mixture of manure and bedding wastes from ISU animal farms and yard and cornstalk wastes from ISU plant facilities. Manure was applied to plots of red clover and alfalfa in the 3-year and 4-year systems in the fall preceding corn at a mean rate of 8.8 metric tons of dry matter per hectare. The composition of the composted manure varied among years, presumably as the result of variations in specific combinations of substrates used to generate the compost and the length of the composting process. Mean concentration of N, P, and $\mathrm{K}$ added by the manure was 128,44 , and $143 \mathrm{~kg} \mathrm{ha}^{-1}$, respectively. Coefficients of variation among years for $\mathrm{N}, \mathrm{P}$, and $\mathrm{K}$ concentrations were 32,57 , and $25 \%$, respectively.

Weed management regime-Subplots. Subplot treatments consisted of two weed management regimes, standard and low herbicide, defined by herbicide, mechanical cultivation, and crop genetics (Table 1). Corn and soybean crops grown under the standard regime received broadcast applications of preemergence (corn) or postemergence (soybean) herbicides (Supplementary Table S3); no interrow cultivations were conducted. Corn and soybean crops grown under the low-herbicide regime received 38 -cm bands of postemergence

Table 1. Field plot treatments used in the long-term cropping system study at Iowa State University's Marsden Farm (Boone, IA) ${ }^{\mathrm{a}}$

\begin{tabular}{|c|c|c|c|c|c|}
\hline \multirow[b]{2}{*}{ Parameters } & \multicolumn{3}{|c|}{ Cropping system (main plot treatments) } & \multicolumn{2}{|c|}{ Weed management regime (subplot treatments) } \\
\hline & 2-year & 3-year & 4-year & Standard & Low-herbicide \\
\hline Year & & & & $\ldots$ & $\ldots$ \\
\hline 1 & Corn & Corn & Corn & $\ldots$ & $\ldots$ \\
\hline 2 & Soybean & Soybean & Soybean & $\ldots$ & $\ldots$ \\
\hline 3 & Corn & Oat + red clover & Oat + alfalfa & $\ldots$ & $\ldots$ \\
\hline 4 & Soybean & Corn & Alfalfa & $\ldots$ & $\ldots$ \\
\hline Fertilization ${ }^{\mathrm{b}}$ & Conventional & Manure + synth & Manure + synth & $\ldots$ & $\ldots$ \\
\hline Herbicide & $\cdots$ & $\cdots$ & $\cdots$ & $\begin{array}{l}\text { Broadcast preemergence (corn) } \\
\text { or postemergence (soybean) }\end{array}$ & $\begin{array}{l}\text { Postemergence herbicides sprayed } \\
\text { over } 38-\mathrm{cm} \text { bands }\end{array}$ \\
\hline Interrow cultivation & $\ldots$ & $\ldots$ & $\ldots$ & None & Once or twice per season \\
\hline Genotype & $\cdots$ & $\cdots$ & $\cdots$ & Transgenic (all years) $^{c}$ & $\begin{array}{l}\text { Nontransgenic in } 2010 \text { to } 2013 \text {, same transgenic } \\
\text { as in standard in } 2014 \text { to } 2015\end{array}$ \\
\hline
\end{tabular}

${ }^{\text {a }}$ Cropping system treatments (comprising crop rotation and fertilization regime) were assigned to 24-row main plots. Weed management regimes (comprising herbicide, tillage, and crop genotype) were assigned to 12-row subplots within each of the main plot. Main plot and subplot treatments were maintained from one year to the next within assigned areas.

${ }^{\mathrm{b}}$ Conventional $=$ synthetic fertilizers at conventional rate and Manure + synth $=$ manure + low synthetic fertilizer rate. The 3-year and 4-year cropping systems utilized farm management practices typical of a row-crop + beef cattle operation; hence, some of the corn nutrient requirement was provided via composted manure.

${ }^{\mathrm{c}}$ Transgenic genotypes $=$ corn hybrid with Bt gene for insect resistance and soybean variety with glyphosate tolerance. Similar hybrids, without transgenic traits, were used in the low-herbicide weed management subplots in 2010 through 2013. In 2014 and 2015, the same corn and soybean varieties were used in both standard and low-herbicide weed management subplots. 
herbicides sprayed over rows; interrow areas were cultivated with sweeps to a depth of $10 \mathrm{~cm}$ once or twice per season. Herbicides used differed between the standard and low-herbicide regimes and varied among years (Hunt et al. 2017), depending on weed species identity, population densities, and stages of development. Choices of herbicides and their application rates followed recommendations from ISU's weed management specialists (Owen and Hartzler 2016). Oat, red clover, and alfalfa main plots were not subjected to different weed management regimes; weeds were suppressed by clipping oat stubble, red clover, and alfalfa 28 to 35 days after oat harvest, and by cutting and removing alfalfa hay three to five times per season.
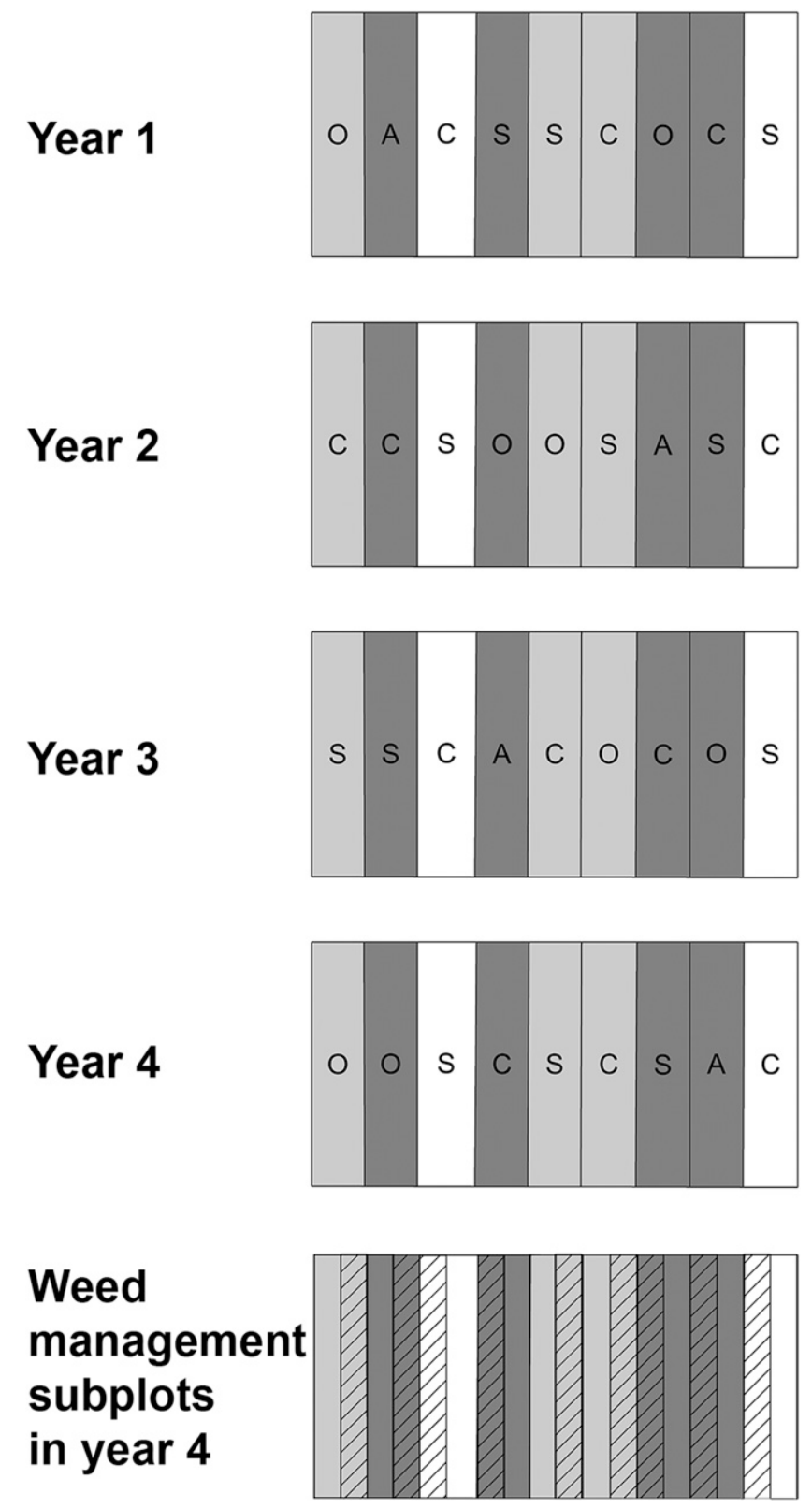

Fig. 1. Diagram showing locations of corn $(C)$, soybean $(S)$, oat $(O)$, and alfalfa $(A)$ plots during an arbitrary 4-year period in one of the four replicate blocks at lowa State University's Marsden Farm long-term cropping system diversification trial. The study used a split-plot, randomized complete block design, with cropping system assigned to main plots and weed management to subplots. Each block has nine plots to accommodate all crop phases of the 2-year (white), 3-year (light gray), and 4 -year (dark gray) cropping system cycles, which were randomly assigned to 18-mwide (24 rows) by 84-m-long main plots. The bottom panel shows locations of the two weed management regimes, which were randomly assigned to 9-m-wide strips (12 rows) in each main plot. In the 3-year system, oat was seeded with red clover. In the 4-year system, oat was seeded with alfalfa, which was maintained into the fourth year.
Crop genotypes. In 2010 to 2013, different corn hybrids and soybean varieties were used in each of the two weed management regimes. Transgenic corn and soybean genotypes were used in the standard regime, and nontransgenic genotypes with similar maturities were used in the low-herbicide regime. This approach allowed a comparison of different "technology packages" (Gómez et al. 2012) but it confounded crop genetics with weed management strategies. Therefore, in 2014 to 2015, a single nontransgenic corn hybrid and a single transgenic soybean variety with glyphosate resistance were used in both the standard and low-herbicide regimes. The transgenic corn hybrid had Bt (Bacillus thuringiensis) traits to control European corn borer (Ostrinia nubilalis) and corn rootworm (Diabrotica spp.), and the transgenic soybean had resistance to the herbicide glyphosate.

Soybean genotypes were from maturity groups 2.7 to 2.9 . The soybean genotypes planted in 2010 to 2013 differed in resistance to SDS. The genotype used in the standard weed management regime in 2010 through 2013 (Kruger K-287RR/SCN) was ranked as highly resistant to SDS in variety trials conducted in 2007 and 2008 at Southern Illinois University at Carbondale (SIUC) (Jason Bond, SIUC, personal communication). In contrast, variety K2918SCN used in the lowherbicide regime was ranked as susceptible based on field trials conducted at the University of Illinois Urbana-Champaign (UIUC) (Wayne Pederson and Keith Ames, UIUC, personal communication). The soybean variety used in 2014 to 2015 , Latham L2758 R2, was rated as resistant in variety trials conducted at SIUC (Jason Bond, SIUC, personal communication). All soybean plots were treated with $\lambda$-cyhalothrin $\left(0.033 \mathrm{~kg}\right.$ a.i. ha $\left.{ }^{-1}\right)$ on 17 July 2013 to suppress Japanese beetle (Popillia japonica); no other insecticides were sprayed during the course of the study.

A single oat variety (IN09201) was used in the 3-year and 4-year cropping systems for the duration of the study. In the 3-year system, Duration red clover was grown with oat in 2010 to 2013 and Southern Belle was used in 2014 to 2015. In the 4-year system, Freedom alfalfa was used for hay production in 2010, FSG 400LH was used in 2011 to 2012, and Pioneer 53H92 was used in 2013 to 2015.

Disease and plant assessments. Soybean plots were evaluated for SDS foliar incidence and severity from 2010 to 2015 (Table 2) when plants were at or close to the R6 (full seed) growth stage (Fehr et al. 1971). From 2010 through 2013, incidence ratings were based on whole-plot estimates of the percentage of plants showing foliar SDS symptoms, and severity was estimated as the percentage of leaf area with SDS symptoms on diseased plants. In 2014 and 2015, incidence and severity were assessed in 10 quadrants, each $4.65 \mathrm{~m}^{2}$, spaced evenly throughout each subplot. In each quadrant, incidence was evaluated as the percentage of plants showing SDS symptoms and severity was evaluated on a 1-to-9 rating scale, where $1=$ low severity and $9=$ high severity (Njiti et al. 1998).

Plants were evaluated for root rot severity and root and shoot weight from 2010 to 2013 (Table 2). In 2010, plants were sampled once at the R5-R6 growth stage (14 September) and rated for root rot severity and root dry weight. In 2011 to 2013, plants were sampled 10 days after emergence (DAE) and at the R2, R3-R4, and R5-R6 growth stages (Table 2). Two plants were arbitrarily sampled at each of five points spaced evenly throughout the length of each subplot. Plants were removed from the soil, shaken to remove the bulk soil, and taken to the lab in coolers within $2 \mathrm{~h}$ of sampling. Shoots were separated from roots at the soil line. Roots were then washed in running tap water and rated for root rot severity, which was evaluated as the percentage of the total root area showing brown or black discoloration. Root and shoot dry weights were measured after oven drying at $70^{\circ} \mathrm{C}$ for $24 \mathrm{~h}$.

The incidence of plants with $F$. virguliforme-infected roots was assessed in 2011 to 2013 (Table 2) by plating root pieces from collected plants. Before roots were oven dried, 5 pieces $(<1 \mathrm{~cm}$ in length) were cut from both tap roots and lateral roots (10 pieces per plant), with preferential selection from discolored root areas, when present. Fresh weights of whole-root systems and root pieces were obtained before they were oven dried. Excised root pieces were surface disinfested in $0.525 \%$ sodium hypochlorite for $2 \mathrm{~min}$, rinsed 
in sterile distilled water, blotted dry on sterile paper towels, and plated on modified Nash-Snyder medium (Rupe et al. 1997). F. virguliforme colonies were identified by visual examination of colony morphology (Aoki and O'Donnell 2003).

Soybean seed yields were determined at crop maturity in all years (Table 2) from six rows and the entire length of each subplot (harvested area $=378 \mathrm{~m}^{2}$ ) using a combine harvester and a weigh wagon. Reported soybean yields were adjusted to $13 \%$ moisture.

Quantification of $\boldsymbol{F}$. virguliforme density in soil. Quantitative polymerase chain reaction (qPCR) was used to determine $F$. virguliforme population density in soil collected from soybean and corn plots from the 2-year and 4-year cropping systems. Samples were collected on 10 October 2012 and 25 July 2013 from the lowherbicide subplots only. Soil was sampled using a $2.54-\mathrm{cm}-$ diameter soil probe inserted to a depth of $15 \mathrm{~cm}$. In 2012, each subplot was divided equally into three sections and four cores were taken from each section, with sampling points located at the corners of a 6.4-by-0.76-m rectangle. At each sampling point, a soil core was taken $5 \mathrm{~cm}$ away from roots, avoiding plant roots and debris. All four soil cores from the same section were placed into a sterile plastic bag and mixed thoroughly; approximately $1 \mathrm{~g}$ of soil was immediately transferred to a sterile, $1.5-\mathrm{ml}$ microfuge tube and placed on dry ice. To minimize microbial and DNA cross-contamination, the soil probes were sprayed with $70 \%$ ethanol and wiped with autoclaved paper towels after sampling each section. In total, 12 pooled soil samples (three sections from a single subplot per treatment, from four replicate blocks) were collected for each treatment in 2012. In 2013, two soil cores, located $12.2 \mathrm{~m}$ apart, were collected from each of three sections per subplot and were again pooled within a section, resulting again in 12 pooled samples per treatment. All soil samples were stored at $-80^{\circ} \mathrm{C}$ until they were used for DNA extraction.

Prior to DNA extraction, microfuge tubes containing frozen soil samples were thawed for 2 to $3 \mathrm{~h}$ on ice. Approximately $0.2 \mathrm{~g}$ of soil was used for DNA extraction following the manufacturer's instructions (PowerLyzer PowerSoil DNA Isolation Kit; MO BIO Laboratories, Inc., Carlsbad, CA), with the homogenization step set at 4,000 rpm for $2 \mathrm{~min}$. The DNA concentration was measured using a NanoDrop 8000 Spectrophotometer (Thermal Scientific, Wilmington, DE) after eluting the samples with $100 \mu \mathrm{l}$ of $10 \mathrm{mM}$ Tris buffer.

To quantify $F$. virguliforme in soil, the qPCR method developed by Wang et al. (2015) was used, with minor modifications. Specifically, the qPCR was carried out in a $10-\mu 1$ reaction, including $5 \mu l$ of KAPA PROBE Force Universal $2 \times$ qPCR Master Mix (Kapa BioSystem, Wilmington, MA), $2 \mu \mathrm{l}$ of template (DNA samples, with and without $10 \times$ dilution), and primers (F6-3 and R6) and probe (F. virguliforme Prb-3) (Wang et al. 2015) at final concentrations of 300 and $150 \mathrm{nM}$, respectively. The following thermal profile was used: 3 min at $98^{\circ} \mathrm{C}$, followed by 40 cycles of $3 \mathrm{~s}$ at $95^{\circ} \mathrm{C}$ and $45 \mathrm{~s}$ at $60^{\circ} \mathrm{C}$, with a threshold cycle set manually at a fluorescence value of 2,000. The copy number of the $F$. virguliforme-specific intergenic spacer (IGS) sequences was estimated using methods described previously (Yang et al. 2016). Briefly, the observed quantitation cycle $(\mathrm{Cq})$ values were fitted into a standard curve, which was obtained by linear regression of $\mathrm{Cq}$ values against log-transformed concentrations of synthetic, double-stranded DNA, which contained targeted IGS priming and probing sites (gBlock; Integrated DNA Technologies, Coralville, IA). For samples with low $F$. virguliforme populations and, hence, with high $\mathrm{Cq}$ values outside the detection limit (logarithm of odds), extrapolation from the standard curve was used, instead of assigning a single Cq value (e.g., 40) to samples outside the detection limit. Our modifications of the original qPCR assay developed by Wang et al. (2015) included reducing the total reaction volume by half, using the rapid cycling thermal profile recommended by the Kapa Probe Force kit, and omitting an internal standard; these enabled us to rapidly quantify $F$. virguliforme populations with PCR efficiencies at or above $98.5 \%$ over a wide range of target concentrations (at least five orders of magnitudes). The detection limit, estimated as 10 to 100 IGS copies per reaction or a $\mathrm{Cq}$ value of 30 to 32 , is similar to those described by previous authors (Kandel et al. 2015; Wang et al. 2015). The specificity of the qPCR assay was validated by including DNA samples (provided by Dr. Kerry O'Donnell, United States Department of Agriculture-Agricultural Research Service) of characterized Fusarium spp. strains capable of causing SDS; only $F$. virguliforme strains produced low $\mathrm{Cq}$ values (data not shown)

Soybean cyst nematode density in soil. Soil population density of the soybean cyst nematode (SCN; Heterodera glycines) was measured in 2010 to 2012. Soil samples were collected on 7 to 11 October 2010, 12 October 2011, and 24 September 2012 from soybean plots each year. Soil was sampled at 20 points within each subplot, with sampling sites evenly distributed along the length of the subplot. Soil cores were collected with a 3.17-cm-diameter soil probe inserted to a depth of $20 \mathrm{~cm}$ and divided into 0 -to-10- and 10-to-20-cm portions; for each subplot, the 20 subsamples for a given depth were pooled. Soil samples were stored at $4^{\circ} \mathrm{C}$ until processing. SCN eggs were counted as described by Faghihi and Ferris (2000).

Data analysis. Data for each year were analyzed separately due to differences in weed management protocols, SDS rating approach, and SDS intensity among years. The variables SDS incidence and severity, root rot severity, root and shoot dry weight, seed yield, and SCN density were analyzed using SAS PROC MIXED (version 9.4; Statistical Analysis Systems, Cary, NC). Cropping system (main plot treatment) and weed management regime (subplot treatment) were classified as fixed factors and block was classified as a random

Table 2. Dates for soybean planting, harvest, and assessments conducted at Marsden Farm from 2010 to 2015

\begin{tabular}{|c|c|c|c|c|c|c|}
\hline \multirow{2}{*}{$\begin{array}{l}\text { Parameters } \\
\text { Soybean planting dates }\end{array}$} & \multicolumn{6}{|c|}{ Assessment dates follow soybean planting dates in each year } \\
\hline & 19 and 25 May $2010^{\mathrm{a}}$ & 18 May 2011 & 14 May 2012 & 15 May 2013 & 23 and 30 May $2014^{\mathrm{a}}$ & 22 May 2015 \\
\hline $\begin{array}{l}\text { Root rot severity (percent root area with dark } \\
\text { discoloration), root dry weight, shoot dry } \\
\text { weight, and incidence }(\%) \text { of plants with } \\
\text { roots colonized by } F \text {. virguliforme at } \\
\text { soybean growth stage }\end{array}$ & & & & & & \\
\hline 10 days after emergence & -- & 3 June & 30 May & 3 June & -- & -- \\
\hline $\mathrm{R} 1$ to $\mathrm{R} 2$ & -- & 5 July & 2 July & 8 July & -- & -- \\
\hline $\mathrm{R} 3$ to $\mathrm{R} 4$ & -- & 1 August & 19 July & 29 July & -- & -- \\
\hline R5 to R6 & 14 September & 24 August & 20 August & 20 August & -- & -- \\
\hline F. virguliforme population density in soil & -- & -- & 10 October & 25 July & -- & -- \\
\hline $\begin{array}{l}\text { SCN population density in soil (eggs in } 100 \\
\mathrm{~cm}^{3} \text { of soil) }\end{array}$ & 7,11 October & 12 October & 24 September & -- & -- & -- \\
\hline SDS foliar incidence and severity ${ }^{c}$ & 3 September & 22 August & 4 September & 4 September & 5 September & 4 September \\
\hline Soybean yield (harvest date) & 5 October & 7 October & 28 September & 10 October & 10 October & 8 October \\
\hline
\end{tabular}


factor. Cropping system effects were tested against the sum of squares for cropping system $\times$ block, while weed management and cropping system $\times$ weed management effects were tested against the residual error. Orthogonal contrasts were used to compare least-squares means for cropping system treatments. The same model and contrasts were employed to compare differences in the frequency of detection of $F$. virguliforme in soybean root systems in the treatments, but SAS PROC GLIMMIX with a logit link function was used due to the binomial nature of the data. Linear regression analyses were conducted using SAS PROC REG to examine the reduction in yield explained by increasing SDS incidence and SDS severity. Regression analyses were conducted for each year, using data per main plot $(n=12)$. Data for $F$. virguliforme density in soil were transformed to the $\log _{10}$ scale and analyzed using the PROC MIXED procedure, with cropping system handled as a fixed factor and block as a random factor. Because $F$. virguliforme density in soil was sampled in both corn and soybean plots, statistical analyses of soil data tested for differences in cropping systems (2-year or 4-year) and crops (corn or soybean) within cropping system. Weed management regime was not included in the model for $F$. virguliforme density in soil because soil samples for $F$. virguliforme quantification were collected only from the low-herbicide subplots.

\section{Results}

Cropping system and weed management regime significantly affected all variables tested. The interaction between cropping system

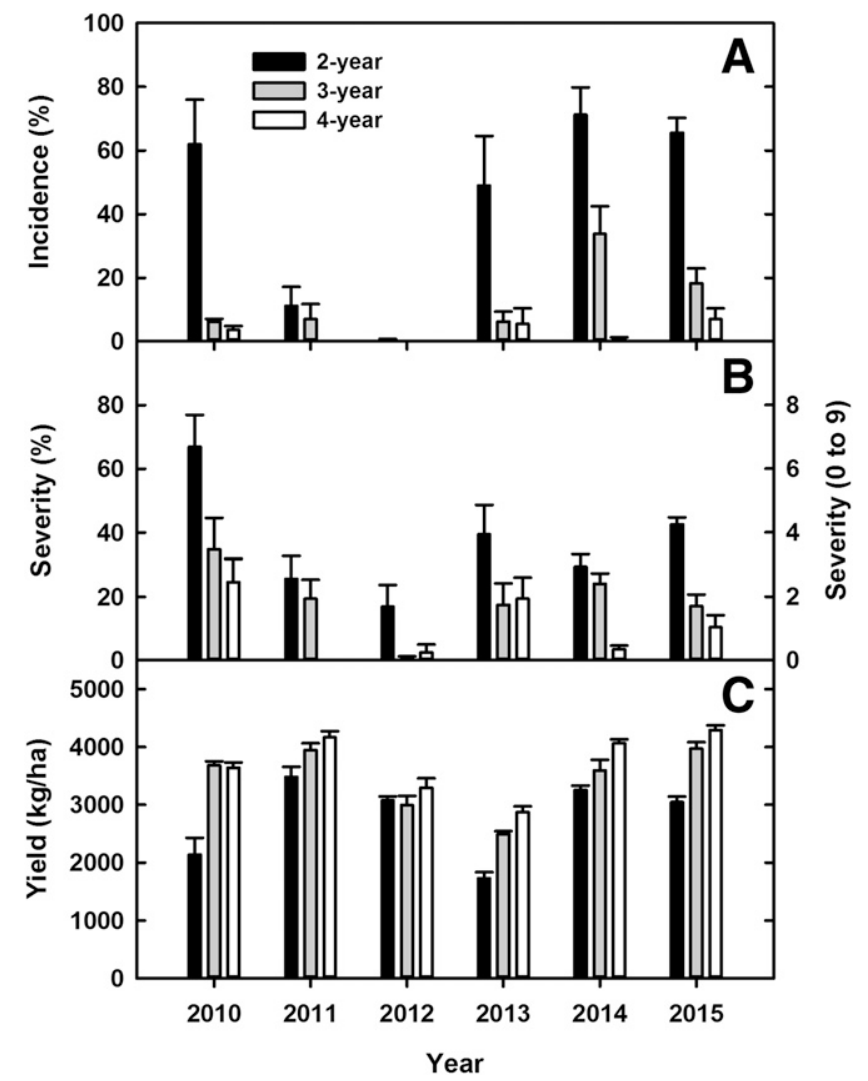

Fig. 2. A, Mean incidence of plants with sudden death syndrome (SDS) foliar symptoms; B, mean severity of SDS symptoms; and C, mean yield in soybean plots in 2-year, 3-year, and 4-year cropping systems (black, gray, and white bars, respectively) near Boone, IA, at the lowa State University Marsden Farm in 2010 through 2015. In 2010 to 2013, incidence and severity were estimated for entire plots, and severity is presented as percent leaf area with SDS symptoms on diseased plants (left axis). In 2014 to 2015 , severity was rated at 10 points in each plot using a 0-to-9 scale (right axis) (Njiti et al. 1998), and averaged. Disease ratings were estimated at soybean growth stage R6. Means presented are for the main effect of cropping system, averaged over weed management regime, because the interaction of cropping system and weed management was generally not significant. Error bars indicate standard errors of mean values. and weed management was not significant for most of the variables and assessment times tested; therefore, data are presented for main plot (cropping system) effects only, except when otherwise noted.

SDS severity and incidence. In all years of the study, foliar SDS symptoms were observed at soybean growth stage R5-R6, with incidence and severity generally being higher in 2010 and 2013 to 2015 and lower in 2011 and 2012 (Fig. 2). The main effect of cropping system was significant in all years for SDS severity and in all years, except 2011 and 2012, for SDS incidence. In these 2 years, weather conditions were unfavorable for disease development due to low precipitation. Mean SDS incidence in the 2-year cropping system reached 49 to $71 \%$ in 2010 and 2013 to 2015; in these years, incidence in 2-year system was consistently higher than incidence in the 3- and 4-year systems $(P<0.05)$ (Fig. 2A). In 2011 and 2012, mean incidence ranged from 0 to $11 \%$, with no differences between cropping system treatments. The mean incidence did not differ between 3-year and 4-year systems in most years. However, in 2014, foliar symptom incidence in the 3-year system varied from 11 to $73 \%$ $($ mean $=34 \%)$ but only from 0 to $3 \%$ in the 4-year system $($ mean $=$ $1 \%)$. The main effect of weed management regime was significant $(P<0.05)$ in 3 years $(2010,2011$, and 2013), when the incidence of SDS was higher in the low-herbicide weed management regime than in the standard system. However, in 2014 and 2015, when the same soybean variety was used in both standard and low-herbicide weed management regimes, SDS incidence was similar in both regimes (data not shown).

Mean SDS severity was greater in the 2-year system compared with the average of the 3- and 4-year systems in all years $(P<$ 0.04) (Fig. 2B). In 2010 and 2013, SDS severity reached 68 and $39 \%$, respectively. In 2014 and 2015, disease severity values, assessed using a 1-to-9 scale (Njiti et al. 1998), indicated that SDS symptoms affected as much as 40 and $60 \%$ of the canopy in 2-year cropping system plots (Fig. 2B). Foliar symptoms were more severe in 3-year than in 4-year system plots in 2011 and $2014(P<0.04)$ but this trend was not observed in the other 4 years of the study.

The main effect of weed management regime was significant $(P<$ 0.05 ) for SDS foliar severity in all years except 2014. In years when weed management differences were present, mean SDS severity was lower in the standard regime than in the low-herbicide regime (data not shown). In 2014 and 2015, when the same soybean variety was used in both standard and low-herbicide weed management regimes, SDS severity in the 2-year cropping system was similar in both (data not shown).

The interaction of cropping system and weed management regime effects influenced SDS incidence in 2010 and 2013 and SDS severity in 2011 and $2012(P<0.05)$. However, the interactions indicated that differences due to cropping system effects differed in magnitude within each weed management regime, whereas response trends were similar. For example, in 2010 , incidence was 27,4 , and $2 \%$ for the standard herbicide system, and 97, 8, and $6 \%$ for the low-herbicide system for the 2-, 3-, and 4-year cropping systems, respectively. A significant interaction was also observed when severity was very low, as in 2012, when severity was $0 \%$ in all cropping system treatments with standard herbicide regime, but $34 \%, 1 \%$ and $5 \%$ in 2-, 3and 4-year systems with the low herbicide. In 2014 and 2015, when weed management regime was not confounded with soybean variety, the interaction of cropping system and weed management was not significant for incidence or severity.

Yield and relationship between yield and SDS. In 5 of the 6 years, mean soybean yields, averaged over both weed management regimes, were significantly lower $(P<0.02)$ in the 2 -year system compared with the average of the 3- and 4-year systems. In 2012, when there was little disease pressure, yield did not differ among treatments (Fig. 2C). Yields in the 3-and 4-year systems were similar in all years except 2015, when yield in the 4-year system was higher $(P=0.05)$. Mean yields in the 2 -year system plots were 0 to $42 \%$ lower than in the 3 -year system plots and 7 to $41 \%$ lower than in the 4-year system plots.

Linear regression analysis showed that yield decreased significantly as SDS incidence and severity increased $(P<0.008)$ in all years except 2012. Data for 2012 were not included in this analysis 
due to low disease pressure associated with drought. SDS incidence explained $87,53,49,64$, and $76 \%$ of the variation in yield and SDS severity explained $45,45,28,57$, and $69 \%$ of the variation in yield in 2010, 2011, 2013, 2014, and 2015, respectively. Over these 5 years, an average of $66 \%$ of the variation in yield was explained by SDS incidence, and SDS severity explained $49 \%$ of the variation in yield.

Yield differed between the two weed management regimes in all years $(P<0.02)$, except 2012 and 2014. From 2010 to 2013, when the two systems used different herbicide regimes and different soybean cultivars, the mean yield from standard management plots (annual yield $=3,249 \mathrm{~kg} \mathrm{ha}^{-1}$ ) was higher than mean yield from low-input plots $\left(3,004 \mathrm{~kg} \mathrm{ha}^{-1}\right)(P=0.0012)$. In contrast, mean yield was lower in the standard system $(3,677 \mathrm{~kg} / \mathrm{ha})$ compared with the low-herbicide system $\left(3,867 \mathrm{~kg} \mathrm{ha}^{-1}\right)$ in $2015(P=0.0376)$, when a single soybean cultivar was used in both herbicide regimes.

Significant interactions between cropping system and weed management regimes were evident in soybean yields for 2010, 2012, and 2013. However, in these years, the cropping system effect was similar within each weed management regime, with lower yields observed in the 2-year system and the highest yields in the 3- and 4- year systems (Fig. 2C). For example, in 2010, yield reductions for 2-year compared with 3 -year systems were $22 \%$ in the standard management treatment and $61 \%$ in the low-herbicide system. In 2014 and 2015 , when weed management regime was not confounded with soybean variety, the interaction of cropping system and weed management regime was not significant.

Root rot severity. Differences in root rot severity were not observed at $10 \mathrm{DAE}$ but cropping system effects $(P<0.05)$ were observed in four of the eight assessments conducted during reproductive growth stages (Fig. 3). Root rot severity tended to increase over the growing season, and was lowest $(<10 \%)$ in 2012, the year with the driest conditions. Orthogonal contrasts showed that root rot severity was significantly greater $(P<0.02)$ in the 2 -year system compared with the average of the 3- and 4-year systems at R1-R2 in 2013, at R3-R4 in 2011 and 2013, and at R5-R6 in 2012. Root rot severity generally did not differ between the 3- and 4-year systems. Root rot severity was not influenced by weed management regime $(P>$ 0.05 ), except on one date in 2011 (10 DAE), when root rot was $4.1 \%$ in the standard regime and $1.9 \%$ in the low-herbicide regime $(P>F=0.0371$; data not shown). The interaction of cropping system and weed management regime never showed a significant impact on root rot severity.

Root and shoot dry weight. Root dry weights were lower in the 2year compared with the 3- and 4-year systems at some but not all assessment times (Fig. 3). Root dry weights were similar in the 3- and 4 -year systems at nearly all assessment times. Orthogonal contrasts showed that root dry weight was lower $(P<0.02)$ in the 2-year system, compared with the average of the 3- and 4-year systems, at R1R2 in 2011 and 2013, at R3-R4 in 2011 and 2013, and at R5-R6 in 2012 and 2013, but never at 10 DAE. Root dry weights in the two weed management regimes differed $(P<0.05)$ at seven assessment times but lower root weights were not consistently associated with a single weed management regime. An interaction of cropping system and weed management regime was not detected in root dry weight data.

The 3-year and 4-year cropping systems had higher shoot dry weights than the 2-year system at the R1-R2, R3-R4, and R5-R6 growth stages in 2011 and $2013(P<0.05)$ (Fig. 4). Cropping system did not influence shoot dry weight in 2012 or at 10 DAE in any of the 3 years. Orthogonal contrasts indicated that shoot dry weights in the 3-year and 4-year systems were similar in all samples, except at the R5 to R6 growth stage in 2013, when 4-year system plots had higher shoot weights (Fig. 4$)(P \leq 0.05)$. Shoot dry weights were greater $(P<0.05)$ in the standard weed management regime than in the low-herbicide regime; this trend was consistent in all assessments except at $10 \mathrm{DAE}$ in 2012. The interaction of cropping system and weed management regime was significant $(P>0.05)$ only at growth stage R2 in 2011.

Incidence of $\boldsymbol{F}$. virguliforme detection in roots. When root tissue samples were plated, $F$. virguliforme was observed infrequently at 10
DAE and at soybean growth stage R1-R2, but detection increased in frequency with plant age. At growth stage R3-R4, $F$. virguliforme was detected in 3 to $40 \%$ of the roots in 2011 to 2013 but differences in cropping systems were not significant (data not shown). At growth stage R5-R6, $F$. virguliforme was isolated from more plants in the 2year system than in the 3- or 4-year systems in $2012(83,7$, and 17\%, respectively; $P<0.05)$ and in $2013(37,17$, and $12 \%$, respectively; $P=0.08$ and 0.03 ), but incidence of $F$. virguliforme detection did not differ in 2011. In all 3 years, cropping system-weed management interactions did not affect the incidence of $F$. virguliforme in soybean root systems.

$F$. virguliforme and $\mathrm{SCN}$ densities in soil. When soil density of the SDS pathogen was estimated based on quantification of $F$. virguliforme targets in the total microbial DNA, higher densities of $F$. virguliforme DNA were detected in soil from 2-year system plots than in soil from the 4-year system (Fig. 5), and these differences were detected in both corn and soybean plots. In 2012, when the F. virguliforme population sizes were estimated after crop harvest, $F$. virguliforme was found to be approximately 5.4 times more abundant in the 2-year than the 4-year system $(P=0.0011)$. In 2013 , when soil samples were collected during the middle of the growing season, similar trends were observed: $F$. virguliforme was more abundant in the 2-year systems for both crops $(P=0.0016$ when averaged over both crops).

In 2010 and 2012, average SCN counts were below 800 eggs per $100 \mathrm{~cm}^{3}$ for all treatments, and there was no significant effect of cropping system and weed management $(P>0.05)$ on SCN population density at either the 0-to-10- or 10-to-20-cm soil depths. In 2011, the main effect of cropping system was significant $(P=0.05)$, with higher SCN counts in the 2-year system $\left(2,781 \mathrm{eggs} \mathrm{cm}^{-3}\right.$ of soil) compared with the 3- and 4-year systems (574 and $900 \mathrm{eggs} \mathrm{cm}^{-3}$ of soil, respectively) at the 0 -to-10-cm depth. There were no differences in egg counts between treatments at the 10-to-20-cm soil depth, where SCN egg counts varied from 141 to 230 eggs $\mathrm{cm}^{-3}$ of soil.

\section{Discussion}

Our findings suggest that cropping system diversification may be used to effectively and sustainably manage SDS. Diversification of the soybean-corn cropping system with oat, and clover or alfalfa, in conjunction with the use of composted manure amendments, greatly suppressed SDS development and protected soybean yield. Previous studies have reported the suppression of SDS or $F$. virguliforme density in soil when soybean was rotated with wheat, sorghum, or fescue (Rupe et al. 1997). Here, we provided the first systematic report of SDS suppression in cropping systems that included extended rotation sequences coupled with the use of organic matter amendments. The effect was consistent over 6 years, even when disease pressure was low. Moreover, we demonstrated that the reduced SDS in the 4-year cropping system was associated with a lower $F$. virguliforme density in soil, as assessed using a sensitive $F$. virguliforme-specific qPCR-based assay, compared with the 2-year system.

Cropping system diversification significantly influenced SDS symptom development in all years of the study. In all 6 years, SDS severity was higher in the 2-year cropping system plots compared with the more diversified systems; foliar symptom severity was up to 17 times higher in the 2-year system compared with the 4-year system. In 5 of the 6 years, SDS incidence was higher in the 2-year cropping system than in the more diversified systems. The effects of cropping system on SDS incidence or foliar severity were observed even in years with low disease expression (2011 and 2012). Greater SDS foliar severity in 2-year system plots was associated with greater root rot severity and lower root dry weights, in at least some of the sampling times in each of the 3 years these variables were measured. Although it is likely that other pathogens or environmental stresses may have contributed to the root discoloration observed, $F$. virguliforme was isolated at higher frequency from roots from the 2-year system compared with the more diversified systems in 2012 and 2013, consistent with root rot trends.

The low levels of SDS in 2011 and 2012 may be explained by the amount of precipitation in those years. Development of SDS is highly 

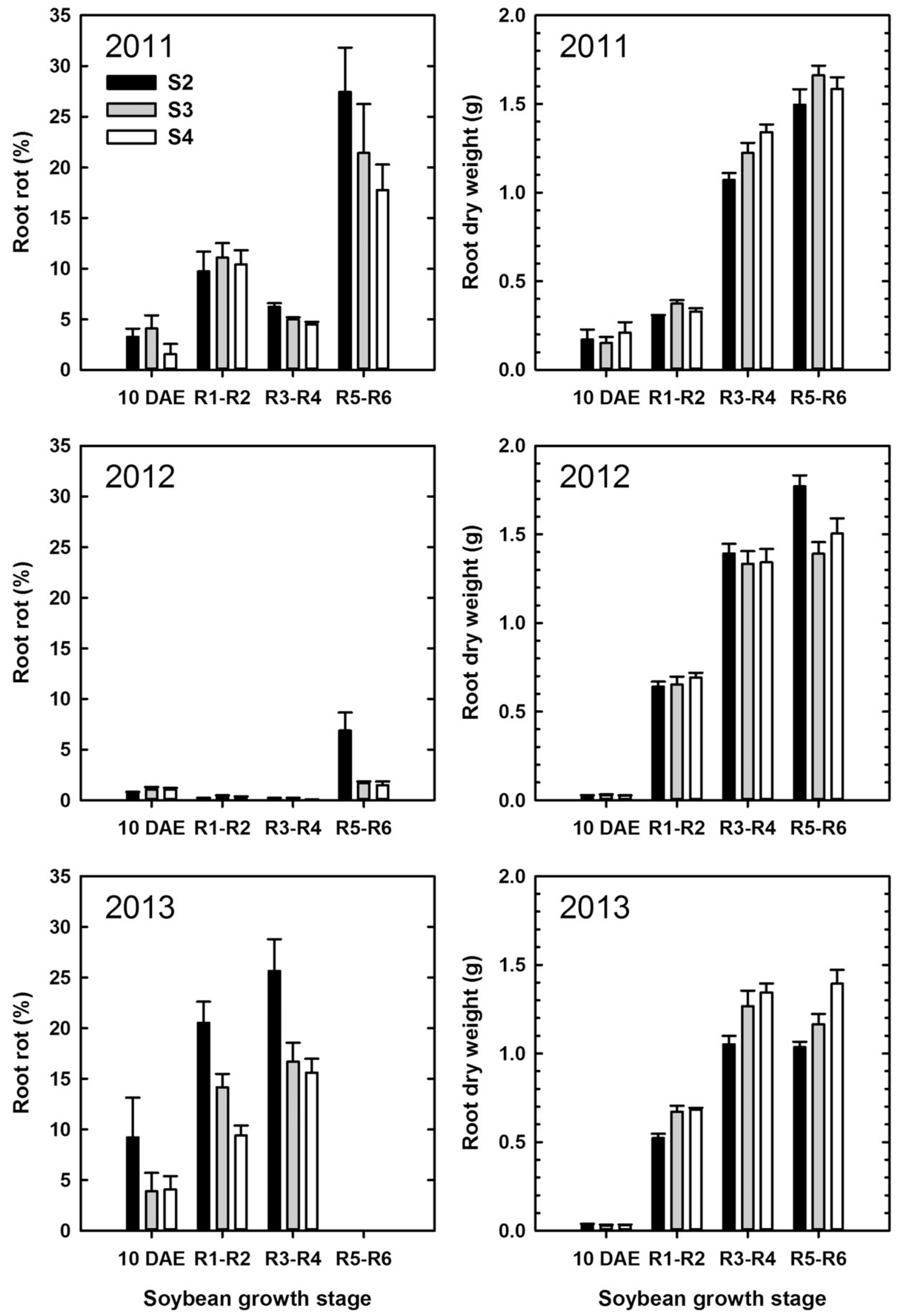

Fig. 3. Mean root rot severity (percent) and root dry weight (grams) assessed at 10 days after emergence (DAE) and at growth stages R1-R2, R3-R4, and R5-R6 in soybean plots in 2-year, 3-year, and 4-year cropping systems (black, gray, and white bars, respectively) near Boone, IA, at the lowa State University Marsden Farm in 2011, 2012, and 2013. Root rot severity was assessed as the percentage of root area showing brown or black discoloration. Means presented are for the main effect of cropping system, averaged over weed management regime, because the interaction of cropping system and weed management was generally not significant. Error bars indicate standard errors of mean values. 
dependent on soil moisture (Leandro et al. 2013; Scherm and Yang 1996), and higher-than-average precipitation, especially during soybean reproductive stages, has been associated with SDS epidemic years (Leandro et al. 2013). In the current study, all 4 years with

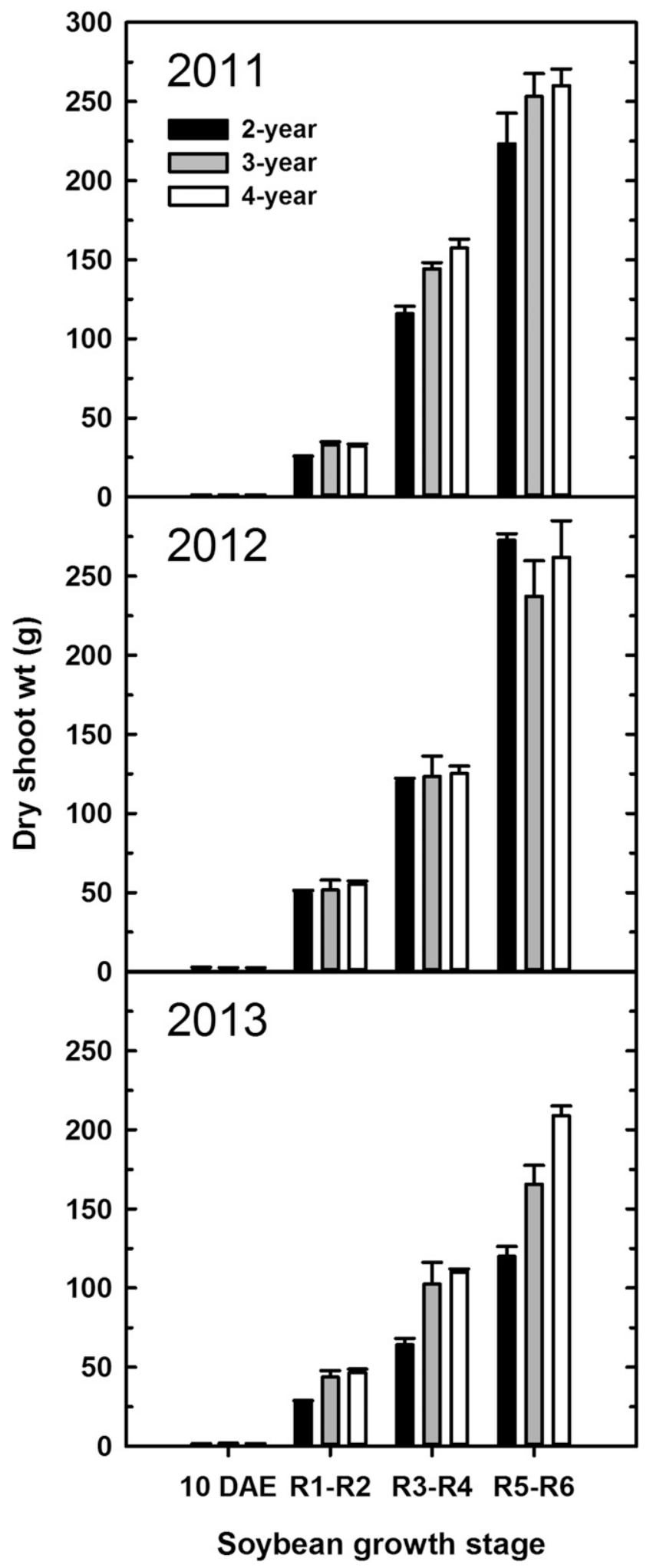

Fig. 4. Dry shoot weights (grams per 10 plants) from soybean plants collected at four growth stages in 2011 through 2013. Shoot samples were collected at 10 days after emergence (DAE) and at soybean growth stages R1-R2, R3-R4, and R5-R6. Main plots ( 18 by $85 \mathrm{~m}$ ) were assigned to 2-, 3-, and 4-year cropping systems (black, gray, and white bars, respectively) using a randomized complete block design with four replications. Means are presented for the main effect of cropping system; the interaction of cropping system and weed management was generally not significant. Error bars indicate standard errors of mean values. severe SDS symptoms had one or more months during the growing season where rainfall greatly exceeded the monthly average. Although cool temperatures have been shown to favor SDS in controlled environments (Gongora-Canul and Leandro 2011b; Scherm and Yang 1996), a close association between soil temperature and SDS epidemics has not been observed in field conditions (Leandro et al. 2013). In 2012, warmer-than-average temperatures in April through June coincided with lower-than-average precipitation but our data are insufficient to demonstrate that temperature influenced SDS development in this study.

Soybean yield was greatly affected by cropping system, and this effect was strongly associated with SDS, which is known to cause devastating yield losses (Hartman et al. 2015a; Leandro et al. 2012). Yields in 3- and 4-year system plots were up to $40 \%$ greater than yields in 2-year system plots. Regression analysis showed that 50 to $87 \%$ of the variation in yield was explained by SDS incidence, and that SDS severity explained 30 to $70 \%$ of the variation in yield. In 2011 and 2012, the years when SDS foliar disease was low, yield differences were smaller, although the same relative effects of cropping system could be observed. This reduction in yield might have been partly caused by root damage caused by $F$. virguliforme infection, because it is possible to have root rot without the expression of foliar symptoms (Gray and Achenbach 1996; Navi and Yang 2008). Our root rot data do not indicate strong associations between root rot severity and yield in all years. This may be due to the fact that plants used for root plating were selected arbitrarily within plots, whereas SDS is known to occur in patches (Roy et al. 1997; Scherm et al. 1998). We sampled only a small number of plants (10 or fewer) from relatively large plots, and plants were selected without prior knowledge of the location of SDS. Consequently, our data may not reflect relationships among root rot severity, incidence of $F$. virguliforme root infection, and yield in patches with high SDS incidence. In addition, research conducted with other root rot pathogens has shown that the impact of root rot on soybean yield is hard to demonstrate (Díaz Arias et al. 2013). The impact of the root rot phase on yield is one of the gaps in knowledge for SDS (Gongora-Canul and Leandro 2011a).

Diversified cropping systems were associated with lower $F$. virguliforme population densities in soil, as demonstrated by quantification

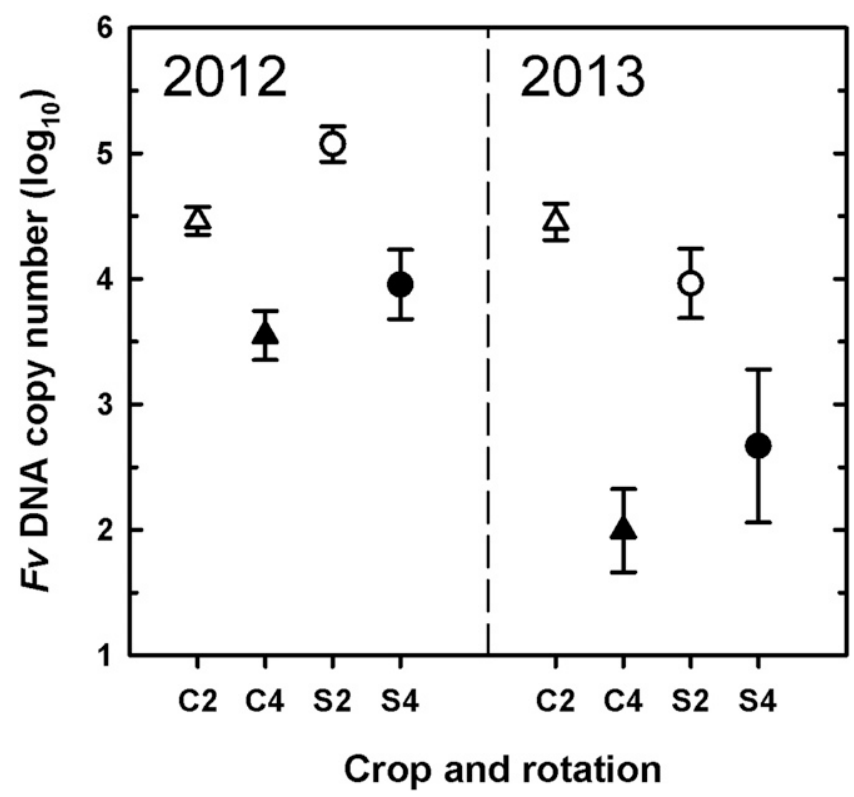

Fig. 5. Abundance ( $\log _{10} \mathrm{scale}$ ) of Fusarium virguliforme (Fv) DNA per gram of soil, determined using single-copy internal transcribed spacer ribosomal DNA targets, in soil samples collected in 2012 and 2013 from soybean (S) and corn (C) plots of the 2- and 4-year cropping systems. Soil samples for pathogen quantification were collected only from the low-herbicide subplots. Error bars indicate standard errors of mean values. 
of $F$. virguliforme using qPCR. In both soybean and corn plots sampled in 2012 and 2013, F. virguliforme density in soil was approximately fivefold greater in the 2-year than in 4-year system plots, showing that the diversified cropping system suppressed pathogen buildup in soil. SDS is an inoculum-dependent disease (Gray and Achenbach 1996; Luckew et al. 2012; Njiti et al. 2001) and, therefore, pathogen density is a critical factor associated with disease intensity. $F$. virguliforme can survive in soil for years as thick-walled chlamydospores (Roy et al. 1997), and rotation with corn has been shown to be ineffective for reducing $F$. virguliforme soil populations or SDS symptoms (Xing and Westphal 2009). The fact that $F$. virguliforme density was higher in both corn and soybean plots in the 2 -year system illustrates the ability of the fungus to maintain viability and high population densities in a corn-soybean rotation, even in the absence of the soybean host crop.

Higher SDS severity and $F$. virguliforme populations in the 2-year system may be the result of the greater frequency of soybean planting in those plots. F. virguliforme can sporulate abundantly in decomposing roots, and $F$. virguliforme populations have been found to peak at harvest (Luo et al. 1999; Rupe et al. 1997, 1999; Wang et al. 2013). This is thought to be one of the causes of inoculum buildup in soil (Roy et al. 1997; Rupe and Becton 1992). In addition, the higher frequency of corn planting in the 2-year cropping system may also play a role. Corn residues have been shown to support survival of $F$. virguliforme in soil (Navi and Yang 2016b) in field and greenhouse studies. Monoculture of soybean in Indiana fields was also reported to suppress SDS in comparison with corn-soybean rotation (Xing and Westphal 2009). It is possible that the alternation of corn and soybean is more conducive to SDS than is interruption of that cycle with other crops.

It is intriguing that alfalfa and clover, which were used in the more diversified cropping systems in the present study, are hosts to F. virguliforme (Kobayashi-Leonel et al. 2015; Kolander et al. 2012). In previous studies, alfalfa and clover developed root rot and showed loss of root mass when infected by $F$. virguliforme (KobayashiLeonel et al. 2015; Kolander et al. 2012). Although the impact of alfalfa and clover on $F$. virguliforme inoculum and SDS has not been tested, it is unlikely that these crops are contributing to suppression of SDS in the more diversified cropping systems. Of particular interest is oat, which was present in both the 3-and 4-year cropping systems, and which may have contributed to suppression of $F$. virguliforme. In a cover crop greenhouse study conducted by Kobayashi-Leonel et al. (2015), oat and other grass species were not hosts to $F$. virguliforme. In addition, oat used in rotation or as a cover crop has been shown to suppress root rot diseases on corn (Darby 2003), pea (WilliamsWoodward et al. 1997), and strawberry (Elmer and LaMondia 1999). Oat roots produce avenacins, which are active saponin compounds that have antimicrobial activity against several fungal pathogens, including Blumeria graminis f. sp. hordei, Bipolaris oryzae, and Magnaporthe oryzae (Inagaki et al. 2013), and several oomycetes (Deacon and Mitchell 1985). It is possible that the oat crop played a role in $F$. virguliforme suppression in our study. However, crop rotations in the more diversified cropping systems have 2- or 3year intervals between the oat crop and the following soybean crop; thus, the mechanisms involved in possible $F$. virguliforme suppression by oat are likely complex.

Because our study examined multifaceted cropping systems and weed management regimes which incorporated numerous farming practices, the roles of individual practices are difficult to discern. With regard to cropping system, crop rotation was confounded with fertilization regime, because manure and lower rates of chemical fertilizer were used in the 3- and 4-year systems, whereas only synthetic fertilizers were used in the 2-year system. Therefore, we cannot conclude from this study whether the suppression of SDS and $F$. virguliforme density in soil was due to the cropping sequence or fertility regime.

Changes in plant-soil relations and soil microbial activity also may have played a role in SDS suppression. In earlier studies at the Marsden Farm trial, aboveground soybean biomass was greater in the 3- and 4-year cropping systems than in the 2-year system
(Lazicki et al. 2016), and soils in the diversified systems had greater microbial biomass than the 2-year system at a depth of 10 to $20 \mathrm{~cm}$ (King 2014). One study in Arkansas reported that F. virguliforme fungal colonies were recovered primarily from the top $15 \mathrm{~cm}$ of soil in an Arkansas field (Rupe et al. 1999). However, the findings from the Arkansas study, which was conducted in a field with a hard pan layer and less organic matter than typical Iowa soils, may not be indicative of the $F$. virguliforme distribution in soils at the Marsden site. Although our study reports $F$. virguliforme detection in soil from a single sampling depth $(0$ to $15 \mathrm{~cm})$, we detected more $F$. virguliforme DNA in soil from the 2-year than the 4-year system. Further work is needed to test the hypotheses that factors promoting robust soybean growth and greater overall microbial biomass may decrease soybean susceptibility to $F$. virguliforme infection.

The use of composted manure in the diversified cropping systems may also have played a role by increasing soil organic matter (Russelle et al. 2007) and affecting microbial communities in the rhizosphere (Bailey and Lazarovits 2003; Bennett et al. 2012; Kirkegaard et al. 2008). In our study, particulate organic matter concentrations were higher in soil samples from diversified system plots than in the 2-year system plots (Liebman et al. 2013). However, Rupe et al. (1993) documented field studies where SDS severity was more severe in soils with high organic matter, whereas Scherm et al. (1998) sampled nine commercial soybean fields and found no association between organic matter and SDS severity. We are currently planning to characterize soil microbial communities at the Marsden Farm site.

A microbial interaction that was of particular interest was the interaction of $F$. virguliforme with SCN. The interaction of SCN with $F$. virguliforme has been shown to increase risk of SDS severity (Leandro et al. 2012; Roy et al. 1989). However, no significant differences were found in SCN counts among cropping systems or weed management regimes in this study, except in 1 year. SCN counts were below or close to 2,000 eggs $\mathrm{cm}^{-3}$ of soil in all treatments, and these population levels are considered low risk to soybean production in the following year (Niblack and Tylka 2016).

Weed management regime also significantly affected SDS, but only in 2010 to 2013. In these years, SDS severity and incidence were lower in the standard herbicide system, where weed management relied on application of glyphosate-based herbicides, than in the lowherbicide system, which used other, band-applied herbicides and interrow cultivation for weed control. Because herbicide type was confounded with cultivation and soybean genotype, it is not possible to identify which specific factor affected disease in these years. However, differences were most likely driven by soybean genotype. In 2010 to 2013, the two weed management regimes used different soybean cultivars. The soybean genotype used in the standard herbicide system in 2010 to 2013 was rated as highly resistant to SDS, whereas the genotype used in the low-herbicide system was rated as susceptible. This is consistent with the disease trends observed in our plots in 2010 to 2013. In 2014 and 2015, when the same soybean genotype was used in both standard and low-herbicide systems, SDS incidence and severity were not affected by weed management regime. This suggests that the different herbicide and cultivation regimes used to manage weeds did not influence SDS. This conclusion is consistent with recent field trials, conducted across various states, which show no effect of glyphosate on SDS (Kandel et al. 2015). Earlier studies had reported an increase in SDS when glyphosate and other herbicides were applied in field conditions (Sanogo et al. 2001). In our study, lower SDS intensity seen in glyphosate-treated plots suggests that weed management regime effects were driven by soybean genotype.

Diversified cropping systems, especially those integrated with livestock production, offer numerous potential environmental and agronomic benefits, including improved soil quality; greater nutrient cycling and retention; greater water-holding capacity; lower rates of soil erosion; improved control of weeds and insect pests; higher rates of crop pollination; reduced reliance on fossil energy; lower risk of failure due to variable markets, weather, and pests; and greater crop productivity (Ball et al. 2005; Bennett et al. 2012; Franzluebbers et al. 2014; Gaudin et al. 2015; Kremen and Miles 2012). In addition 
to these benefits, diversified cropping systems can suppress certain crop diseases (Abawi and Widmer 2000; Curl 1963; Kirkegaard et al. 2008; Peters et al. 2003). Our study provides the strongest evidence to date that diversified cropping systems can effectively suppress SDS. Adoption of diversified systems will require growers to learn new practices and adapt to new farming equipment. However, the environmental and disease management benefits of diversified cropping systems, combined with the fact that profitability is as high or higher compared with the dominant corn-soybean system (Davis et al. 2012; Gómez et al. 2012; Liebman et al. 2008), make it a promising alternative to growers.

Although this study took place in a single location, it clearly shows that diversified cropping systems can have a dramatic effect on SDS. Future work should focus on determining the mechanisms of SDS suppression and conducting similar studies at more locations to verify whether the effects are broadly applicable.

\section{Acknowledgments}

We thank A. Lauter, M. Agudelo, D. Sundberg, N. Tatalovic, and M. Woods for assisting with sample collection, processing, and data collection; and K. O'Donnell, United States Department of Agriculture-Agricultural Research Service, for providing DNA samples for the qPCR reactions.

\section{Literature Cited}

Abawi, G. S., and Widmer, T. L. 2000. Impact of soil health management practices on soilborne pathogens, nematodes and root diseases of vegetable crops. Appl. Soil Ecol. 15:37-47.

Allen, T. W., Bradley, C. A., Sisson, A. J., Byamukama, E., Chilvers, M. I. 2017. Soybean yield loss estimates due to diseases in the United States and Ontario, Canada, from 2010 to 2014. Plant Health Prog. 18:19-27.

Aoki, T., and O'Donnell, K. 2003. Sudden-death syndrome of soybean is caused by two morphologically and phylogenetically distinct species within the Fusarium solani species complex - F. virguliforme in North America and F. tucumaniae in South America. Mycologia 95:660-684.

Aoki, T., Scandiani, M. M., and O'Donnell, K. 2012. Phenotypic, molecular phylogenetic and pathogenic characterization of Fusarium crassistipitatum sp. nov., a novel soybean sudden death syndrome pathogen from Argentina and Brazil. Mycoscience 53:167-186.

Bailey, K. L., and Lazarovits, G. 2003. Suppressing soil-borne diseases with residue management and organic amendments. Soil Tillage Res. 72:169-180.

Ball, B. C., Bingham, I., Rees, R. M., Watson, C. A., and Litterick, A. 2005. The role of crop rotations in determining soil structure and crop growth conditions. Can. J. Soil Sci. 85:557-577.

Bennett, A. J., Bending, G. D., Chandler, D., Hilton, S., and Mills, P. 2012. Meeting the demand for crop production: The challenge of yield decline in crops grown in short rotations. Biol. Rev. 87:52-71.

Brar, H. K., Swaminathan, S., and Bhattacharyya, M. K. 2011. The Fusarium virguliforme toxin FvToxl causes foliar sudden death syndrome-like symptoms in soybean. Mol. Plant-Microbe Interact. 24:1179-1188.

Curl, E. A. 1963. Control of plant diseases by crop rotation. Bot. Rev. 29:413-479.

Darby, H. M. 2003. Soil organic matter management and root health. Ph.D. dissertation, Oregon State University, Corvallis.

Davis, A. S., Hill, J. D., Chase, C. A., Johanns, A. M., and Liebman, M. 2012. Increasing cropping system diversity balances productivity, profitability and environmental health. PLoS One 7:e47149.

Deacon, J. W., and Mitchell, R. T. 1985. Toxicity of oat roots, oat root extracts, and saponins to zoospores of Pythium spp. and other fungi. Trans. Br. Mycol. Soc. 84:479-487.

de Farias Neto, A. L., Hartman, G. L., Pedersen, W. L., Li, S., Bollero, G. A., and Diers, B. W. 2006. Irrigation and inoculation treatments that increase the severity of soybean sudden death syndrome in the field. Crop Sci. 46: 2547-2554.

Díaz Arias, M. M., Leandro, L. F., and Munkvold, G. P. 2013. Aggressiveness of Fusarium species and impact of root infection on growth and yield of soybeans. Phytopathology 103:822-832.

Elmer, W. H., and LaMondia, J. L. 1999. Influence of ammonium sulfate and rotation crops on strawberry black root rot. Plant Dis. 83:119-123.

Faghihi, J., and Ferris, J. M. 2000. An efficient new device to release eggs from Heterodera glycines. J. Nematol. 32:411-413.

Fehr, W. R., Caviness, C. E., Burmood, D. T., and Pennington, J. S. 1971. Stage of development descriptions for soybeans, Glycine max (L.) Merrill. Crop Sci. 11:929-931.

Franzluebbers, A. J., Sawchik, J., and Taboada, M. A. 2014. Agronomic and environmental impacts of pasture-crop rotations in temperate North and South America. Agric. Ecosyst. Environ. 190:18-26.

Gao, X., Hartman, G., and Niblack, T. 2006. Early infection of soybean roots by Fusarium solani f. sp. glycines. (Abstr.) Phytopathology 96:S38.

Gaudin, A. C. M., Tolhurst, T. N., Ker, A. P., Janovicek, K., Tortora, C., Martin, R. C., and Deen, W. 2015. Increasing crop diversity mitigates weather variations and improves yield stability. PLoS One 10:e0113261.
Gómez, R., Liebman, M., Sundberg, D. N., and Chase, C. A. 2012. Comparison of crop management strategies involving crop genotype and weed management practices in conventional and more diverse cropping systems. Renew. Agric. Food Syst. 28:220-233.

Gongora-Canul, C. C., and Leandro, L. F. S. 2011a. Plant age affects root infection and development of foliar symptoms of soybean sudden death syndrome. Plant Dis. 95:242-247.

Gongora-Canul, C. C., and Leandro, L. F. S. 2011b. Effect of soil temperature and plant age at time of inoculation on progress of root rot and foliar symptoms of soybean sudden death syndrome. Plant Dis. 95:436-440.

Gray, L. E., and Achenbach, L. A. 1996. Severity of foliar symptoms and root and crown rot of soybean inoculated with various isolates and inoculum rates of Fusarium solani. Plant Dis. 80:1197-1199.

Hartman, G. L., Chang, H.-X., and Leandro, L. F. 2015a. Research advances and management of soybean sudden death syndrome. Crop Prot. 73:60-66.

Hartman, G. L., Leandro, L. F., and Rupe, J. C. 2015b. Sudden death syndrome Pages 88-90 in: Compendium of Soybean Diseases and Pests, 5th ed. G. L. Hartman, J. C. Rupe, E. J. Sikora, L. L. Domier, J. A. Davis, and K. L. Steffey, eds. American Phytopathological Society, St. Paul, MN.

Hershman, D., Hendrix, J., Stuckey, R., Bachi, P., and Henson, G. 1990. Influence of planting date and cultivar on soybean sudden death syndrome in Kentucky. Plant Dis. 74:761-766.

Huang, Y. H., and Hartman, G. L. 1998. Reaction of selected soybean genotypes to isolates of Fusarium solani f. sp. glycines and their culture filtrates. Plant Dis. 82:999-1002.

Hunt, N., Hill, J., and Liebman, M. 2017. Reducing freshwater toxicity while maintaining weed control, profits, and productivity: Effects of increased crop rotation diversity and reduced herbicide usage. Environ. Sci. Technol. 51: 1707-1717.

Inagaki, Y.-S., Noutoshi, Y., Fujita, K., Imaoka, A., Arase, S., Toyoda, K., Shiraishi, T., and Ichinose, Y. 2013. Infection-inhibition activity of avenacin saponins against the fungal pathogens Blumeria graminis f. sp. hordei, Bipolaris oryzae, and Magnaporthe oryzae. J. Gen. Pathol. 79:69-73.

Kandel, Y. R., Haudenshield, J. S., Srour, A. Y., Islam, K. T., Fakhoury, A. M. Santos, P., Wang, J., Chilvers, M. I., Hartman, G. L., Malvick, D. K., Floyd, C. M., Mueller, D. S., and Leandro, L. F. S. 2015. Multilaboratory comparison of quantitative PCR assays for detection and quantification of Fusarium virguliforme from soybean roots and soil. Phytopathology 105: 1601-1611

Kandel, Y. R., Wise, K. A., Bradley, C. A., Chilvers, M. I., Tenuta, A. U., and Mueller, D. S. 2016a. Fungicide and cultivar effects on sudden death syndrome and yield of soybean. Plant Dis. 100:1339-1350.

Kandel, Y. R., Wise, K. A., Bradley, C. A., Tenuta, A. U., and Mueller, D. S. 2016b. Effect of planting date, seed treatment, and cultivar on plant population, sudden death syndrome, and yield of soybean. Plant Dis. 100 $1735-1743$.

Karlen, D. L., Varvel, G. E., Bullock, D. G., and Cruse, R. M. 1994. Crop rotations for the 21st century. Adv. Agron. 53:1-45.

King, A. E. 2014. Multifunctional agriculture: Root and nitrogen dynamics in two alternative systems. M.S. thesis, Iowa State University, Ames.

Kirkegaard, J., Christen, O., Krupinsky, J., and Layzell, D. 2008. Break crop benefits in temperate wheat production. Field Crops Res. 107:185-195.

Kobayashi-Leonel, R., Mueller, D. S., and Leandro, L. F. S. 2015. Evaluation of cover crop susceptibility to Fusarium virguliforme, the causal agent of sudden death syndrome of soybean. (Abstr.) Phytopathology 105:S4.74

Kolander, T. M., Bienapfl, J. C., Kurle, J. E., and Malvick, D. K. 2012. Symptomatic and asymptomatic host range of Fusarium virguliforme, the causal agent of soybean sudden death syndrome. Plant Dis. 96:1148-1153.

Kremen, C., and Miles, A. 2012. Ecosystem services in biologically diversified versus conventional farming systems: Benefits, externalities, and trade-offs. Ecol. Soc. 17:40.

Lazicki, P. A., Liebman, M., and Wander, M. M. 2016. Root parameters show how management alters resource distribution and soil quality in conventional and low-input cropping systems in central Iowa. PLoS One 11:e0164209.

Leandro, L. F., Tatalovic, N., and Luckew, A. 2012. Soybean sudden death syndrome-Advances in knowledge and disease management. CAB Rev. 7: $1-14$

Leandro, L. F. S., Robertson, A. E., Mueller, D. S., and Yang, X. B. 2013. Climatic and environmental trends observed during epidemic and non-epidemic years of soybean sudden death syndrome in Iowa. Online publication. Plant Health Prog. doi.org/10.1094/PHP-2013-0529-01-RS

Liebman, M., Chase, C., Wander, M., and Tomer, M. D. 2013. Impacts of conventional and diversified rotational systems on crop yields, profitability, soil functions and environmental quality. Online publication. Leopold Center Completed Grant Reports, Paper 431. https://lib.dr.iastate.edu/ leopold_grantreports/431

Liebman, M., Gibson, L. R., Sundberg, D. N., Heggenstaller, A. H., Westerman, P. R., Chase, C. A., Hartzler, R. G., Menalled, F. D., Davis, A. S., and Dixon, P. M. 2008. Agronomic and economic performance characteristics of conventional and low-external-input cropping systems in the central Corn Belt. Agron. J. 100:600-610.

Liebman, M., and Staver, C. P. 2001. Crop diversification for weed management Pages 322-374 in: Ecological Management of Agricultural Weeds. M. 
Liebman, C. L. Mohler, and C. P. Staver, eds. Cambridge University Press, Cambridge, UK

Lightfoot, D. A. 2015. Two decades of molecular marker-assisted breeding for resistance to soybean sudden death syndrome. Crop Sci. 55:1460-1484.

Luckew, A. S., Cianzio, S. R., and Leandro, L. F. 2012. Screening method for distinguishing soybean resistance to Fusarium virguliforme in resistant $\times$ resistant crosses. Crop Sci. 52:2215-2223.

Luo, Y., Myers, O., Lightfoot, D. A., and Schmidt, M. E. 1999. Root colonization of soybean cultivars in the field by Fusarium solani f. sp. glycines. Plant Dis. 83:1155-1159

Magdoff, F., Lanyon, L., and Liebhardt, B. 1997. Nutrient cycling, transformations, and flows: Implications for a more sustainable agriculture. Adv. Agron. 60:1-73.

Marzano, S.-Y. L., Villamil, M. B., Wander, M. M., Ugarte, C. M., Wen, L., and Eastburn, D. M. 2015. Organic transition effects on soilborne diseases of soybean and populations of Pseudomonadaceae. Agron. J. 107:1087-1097.

Navi, S. S., and Yang, X. B. 2008. Foliar symptom expression in association with early infection and xylem colonization by Fusarium virguliforme (formerly F. solani f. sp. glycines), the causal agent of soybean sudden death syndrome. Online publication. Plant Health Prog. doi.org/10.1094/PHP-2008-0222-01-RS

Navi, S. S., and Yang, X. B. 2016a. Impact of crop residue and corn-soybean rotation on the survival of Fusarium virguliforme a causal agent of sudden death syndrome of soybean. J. Plant Pathol. Microbiol. 7:330.

Navi, S. S., and Yang, X. B. 2016b. Sudden death syndrome-A growing threat of losses in soybeans. CAB Rev. 11:1-13.

Niblack, T. L., and Tylka, G. L., eds. 2016. Soybean Cyst Nematode Management Guide, 5th ed. Online publication. North Central Soybean Research Program. http://soybeanresearchinfo.com/pdf_docs/SCNGuide_5thEd.pdf

Njiti, V. N., Johnson, J. E., Torto, T. A., Gray, L. E., and Lightfoot, D. A. 2001. Inoculum rate influences selection for field resistance to soybean sudden death syndrome in the greenhouse. Crop Sci. 41:1726-1731.

Njiti, V. N., Shenaut, M. A., Suttner, R. J., Schmidt, M. E., and Gibson, P. T. 1998. Relationship between soybean sudden death syndrome disease measures and yield components in F6-derived lines. Crop Sci. 38:673-678.

Owen, M. D., and Hartzler, R. 2016. 2017 Herbicide Guide for Iowa Corn and Soybean Production. Online publication. Iowa State University Extension Store, WC 94. https://crops.extension.iastate.edu/files/page/files/wc94.pdf

Perez-Brandan, C., Arzeno, J. L., Huidobro, J., Conforto, C., Grumberg, B., Hilton, S., Bending, G. D., Meriles, J. M., and Vargas-Gil, S. 2014. The effect of crop sequences on soil microbial, chemical and physical indicators and its relationship with soybean sudden death syndrome (complex of Fusarium species). Span. J. Agric. Res. 12:252-264.

Peters, R. D., Sturz, A. V., Carter, M. R., and Sanderson, J. B. 2003. Developing disease-suppressive soils through crop rotation and tillage management practices. Soil Tillage Res. 72:181-192.

Power, J. F., and Follett, R. F. 1987. Monoculture. Sci. Am. 256:78-86.

Roy, K. W., Lawrence, G. W., Hodges, H. H., McLean, K. S., and Killebrew, J. F. 1989. Sudden death syndrome of soybean: Fusarium solani as incitant and relation of Heterodera glycines to disease severity. Phytopathology 79:191-197.

Roy, K. W., Rupe, J. C., Hershman, D. E., and Abney, T. S. 1997. Sudden death syndrome of soybean. Plant Dis. 81:1100-1111.

Rupe, J. C., and Becton, C. M. 1992. Vertical distribution of Fusarium solani, causal agent of sudden death syndrome of soybean, in two Arkansas fields. (Abstr.) Phytopathology 82:1134.
Rupe, J. C., and Gbur, E. E., Jr. 1995. Effect of plant age, maturity group and the environment on the disease progress of sudden death syndrome of soybean. Plant Dis. 79:139-143.

Rupe, J. C., Robbins, R. T., Becton, C. M., Sabbe, W. A., and Gbur, E. E., Jr. 1999 Vertical and temporal distribution of Fusarium solani and Heterodera glycines in fields with sudden death syndrome of soybean. Soil Biol. Biochem. 31: $245-251$.

Rupe, J. C., Robbins, R. T., and Gbur, E. E., Jr. 1997. Effect of crop rotation on soil population densities of Fusarium solani and Heterodera glycines and on the development of sudden death syndrome of soybean. Crop Prot. 16:575-580.

Rupe, J. C., Sabbe, W. E., Robbins, R. T., and Gbur, E. E. 1993. Soil and plant factors associated with sudden death syndrome of soybean. J. Prod. Agric. 6: 218-221.

Russelle, M. P., Entz, M. H., and Franzluebbers, A. J. 2007. Reconsidering integrated crop-livestock systems in North America. Agron. J. 99:325-334.

Sanogo, S., Yang, X. B., and Lundeen, P. 2001. Field response of glyphosatetolerant soybean to herbicides and sudden death syndrome. Plant Dis. 85: 773-779.

Scherm, H., and Yang, X. 1996. Development of sudden death syndrome of soybean in relation to soil temperature and soil water matric potential. Phytopathology 86:642-649.

Scherm, H., and Yang, X. 1999. Risk assessment for sudden death syndrome of soybean in the north-central United States. Agric. Syst. 59:301-310.

Scherm, H., Yang, X., and Lundeen, P. 1998. Soil variables associated with sudden death syndrome in soybean fields in Iowa. Plant Dis. 82:1152-1157.

Sulc, R. M., and Tracy, B. F. 2007. Integrated crop-livestock systems in the U.S Corn Belt. Agron. J. 99:335-345.

Wang, J., Jacobs, J. L., Byrne, J. M., and Chilvers, M. I. 2015. Improved diagnoses and quantification of Fusarium virguliforme, causal agent of soybean sudden death syndrome. Phytopathology 105:378-387.

Wang, J., Jacobs, J. L., and Chilvers, M. I. 2013. Temporal dynamics of soybean root colonization by Fusarium virguliforme. (Abstr.) Phytopathology 103 S2.157.

Weems, J. D., Haudenshield, J. S., Bond, J. P., Hartman, G. L., Ames, K. A., and Bradley, C. A. 2015. Effect of fungicide seed treatments on Fusarium virguliforme infection of soybean and development of sudden death syndrome. Can. J. Plant Pathol. 37:435-447.

Westphal, A., and Xing, L. 2011. Soil suppressiveness against the disease complex of the soybean cyst nematode and sudden death syndrome of soybean. Phytopathology 101:878-886.

Williams-Woodward, J. L., Pfleger, F. L., Fritz-Vincent, A., and Allmaras, R. R. 1997. Green manures of oat, rape, and sweet corn for reducing common root rot in pea (Pisum sativum) caused by Aphanomyces euteiches. Plant Soil 188: 43-48.

Wrather, A., Shannon, G., Balardin, R., Carregal, L., Escobar, R., Gupta, G. K., Ma, Z., Morel, W., Ploper, D., and Tenuta, A. 2010. Effect of diseases on soybean yield in the top eight producing countries in 2006. Online publication. Plant Health Prog. doi.org/10.1094/PHP-2010-0125-01-RS

Xing, L. J., and Westphal, A. 2009. Effects of crop rotation of soybean with corn on severity of sudden death syndrome and population densities of Heterodera glycines in naturally infested soil. Field Crops Res. 112:107-117.

Yang, S., Li, X., Chen, C., Kyveryga, P., and Yang, X. B. 2016. Assessing fieldspecific risk of soybean sudden death syndrome using satellite imagery in Iowa. Phytopathology 106:842-853. 